\title{
Exposure Science in a Climate Change Scenario
}

\author{
Susana Viegas \\ Escola Nacional de Saúde Pública, Universidade Nova de Lisboa, Lisboa, Portugal
}

Climate change and the consequent changes of the environmental conditions bring several challenges to public health. The rising average temperatures, altered rainfall patterns, and other extreme events occurring due to climate change are beginning to reverse years of improvement in managing food and water insecurity particularly in some parts of the world, putting even more at-risk basic needs crucial for good health [1]. Other challenges, such as agricultural workers' exposure to extreme temperatures, the increased use of pesticides, and the improved conditions for the transmission of many water-borne, air-borne, food-borne, and vector-borne pathogens, are also relevant to mention and to tackle with suitable and multi-sectorial adaptation measures [2-4].

But in this scenario, why is exposure science important?

Exposure science studies the contact between stressors and receptors and the associated exposure sources, exposure pathways, and processes potentially leading to impacts on human health and the natural and built environment. Stressors primarily refer to chemical, biological, and physical agents, and receptors range from molecules, cells, and organs to humans and other organisms [5]. Human exposure science is a critical component of the risk assessment process and is essential for establishing solid links in the environmental source-to-health outcome continuum and generating information that can be used to mitigate or prevent future adverse exposures $[6,7]$.

With the climate change scenario, exposure sources, stressors, and even exposure pathways can change and impact differently in human health. Changes in climate such as changes in temperature can directly prompt health-threatening exposures (for example, extreme heat events) or, indirectly, change the exposure patterns to chemical substances. This last case is not being discussed extensively and only in some specific situations, scarce scientific outputs are being produced.

Mycotoxins are a group of highly toxic natural toxins that are produced by toxigenic moulds that commonly grow on several crops and are recognized to be carcinogenic, immunosuppressive, neurotoxic, estrogenic, or teratogenic activity and some mycotoxins have more than one of these effects. Although the impact of climate change on fungal colonization has not yet been specifically and thoroughly addressed, temperature, humidity and precipitation are known to affect toxigenic moulds and their capacity to produce mycotoxins [8]. This might result in different human exposure patterns through food consumption, related to the type of mycotoxin being produced in the crop and during the different steps of the crop processing. For instance, the low levels of aflatoxin B1 (AFB1), a carcinogenic mycotoxin, normally reported in European countries, can change particularly under a (c) 2022 The Author(s). Published by S. Karger AG, Basel on behalf of NOVA National School of Public Health

This is an Open Access article licensed under the Creative Commons Attribution-NonCommercial-4.0 International License (CC BY-NC) (http://www.karger.com/Services/OpenAccessLicense), applicable to the online version of the article only. Usage and distribution for commercial purposes requires written permission.
Correspondence to:

Susana Viegas, susana.viegas@ensp.unl.pt 
climate change scenario, and a possible increase in AFB1 contamination for feed ingredients and food commodities, such as cereals, has been predicted [9]. Climate change will affect cereals production, agricultural practices, and the ecological niches of mycotoxigenic fungi in particular areas. In the future, mycotoxin producers in temperate climates will be substituted by better-adapted species or mutants, which may produce new mycotoxins [9-11].

It is predicted that aflatoxin contamination and the associated food safety issues will become prevalent in Europe with a temperature increase of $+2^{\circ} \mathrm{C}[9,12]$. Related to this, the NOVA National School of Public Health is coordinating a project funded by the EEA grants that intend to provide some additional predictions on what can be expected concerning mycotoxins exposure in two countries from Europe, Portugal and Iceland (https:// www.ensp.unl.pt/projectos/mycoclimachange-exposure-to-mycotoxins-in-a-climate-change-scenario/).

However, other exposure scenarios need to be considered that will also be impacted by climate change. The occupational exposure to mycotoxins occurring during tasks involving high exposure to organic dust, such as storage work, loading, handling, or milling contaminated materials (grain, feed, and waste), and others such as caring for animals in animal husbandry settings can also be altered due to changes in fungal and mycotoxins contamination of the raw materials being handled $[11,13]$.

Therefore, besides the urgent need for accelerating progress on mitigation and adaptation measures at the global level, there is also the need to increase knowledge on the changes of human exposure patterns to chemicals due to climatic environmental changes. We need to be able to recognize the new and different stressors to human health that can emerge from climate change, understand how exposure can happen to provide an appropriate answer also from the public health perspective.

As a result, exposure science will play a capital role in decision-making in several areas, including climate change mitigation and adaptation, providing relevant information for regulatory and policy agencies allowing informed decisions by multiple stakeholders and policy actors. Indeed, we need a more proactive and acknowledgeable approach to tackle climate change challenges and exposure science can contribute to delivering the knowledge needed!

\section{Conflict of Interest Statement}

The author does not have any conflicts of interest to declare.

\section{References}

1 Romanello M, McGushin A, Di Napoli C, Drummond P, Hughes N, Jamart L, et al. The 2021 report of the Lancet Countdown on health and climate change: code red for a healthyfuture.Lancet.2021;398(10311):161962.

2 Rhodes LA, McCarl BA. An analysis of climate impacts on herbicide, insecticide, and fungicide expenditures. Agronomy (Basel). 2020;10(5):745.

3 Tavares AB, Viegas S, Sousa-Uva A. Public health and climate change: do we need a more proactive approach? Port J Public Health. 2019;37(2-3):55-6.

4 Viegas S. Climate change and the need of a one health approach: from science to policy. Eur J Public Health. 2021;31(3 Supplement_3):iii103-103.

5 Heinemeyer G, Connolly A, von Goetz N, Bessems J, Bruinen de Bruin Y, Coggins MA, et al. Towards further harmonization of a glossary for exposure science-an ISES Europe statement. J Expo Sci Environ Epidemiol. 2021. https://doi.org/10.1038/s41370-02100390-w.
6 Committee on Human and Environmental Exposure Science in the 21st Century. Board on Environmental Studies and Toxicology. Division on Earth and Life Studies. National Research Council. Applications of exposure science. Committee on Human and Environmental Exposure Science in the 21st Century. Board on Environmental Studies and Toxicology. Division on Earth and Life Studies. National Research Council. Exposure science in the 21st century: a vision and a strategy. Washington (DC): National Academies Press; 2012. pp. 50-89.

7 Barr D. Human exposure science: a field of growing importance. J Expo Sci Environ Epidemiol. 2006;16(6):473.

8 Jaykus LA, Woolridge M, Frank MJ, Miraglia M, McQuatters-Gollop A, Tirado C, et al. Climate change: implications for food safety. Rome: The Food and Agriculture Organization (FAO); 2008.
9 Battilani P, Toscano P, Van der Fels-Klerx HJ, Moretti A, Camardo Leggieri M, Brera C, et al. Aflatoxin B1 contamination in maize in Europe increases due to climate change. Sci Rep. 2016 Apr;6(1):24328.

10 Assunção R, Martins C, Viegas S, Viegas C, Jakobsen LS, Pires S, et al. Climate change and the health impact of aflatoxins exposure in Portugal - an overview. Food Addit Contam Part A Chem Anal Control Expo Risk Assess. 2018 Aug;35(8):1610-21.

11 Viegas S, Assunção R, Twarużek M, Kosicki R, Grajewski J, Viegas C. Mycotoxins feed contamination in a dairy farm - potential implications for milk contamination and workers' exposure in a One Health approach. J Sci Food Agric. 2020 Feb;100(3):1118-23.

12 WHO. Food safety climate change and the role of WHO. Geneva: World Health Organization; 2018. (WHO/NHM/FOS/RAM/18.4).

13 Viegas S, Viegas C, Oppliger A. Occupational exposure to mycotoxins: current knowledge and prospects. Ann Work Expo Health. 2018 Oct;62(8):923-41. 